\title{
North Aceh Regional Innovation Policy in the face of reduced Regional Fiscal Capacity after the end operational PT. Arun. LNG
}

\author{
Ferizaldi ${ }^{1}$, Muhammad Hasyem² \\ 1,Public Administration Departement, Faculty of Sosial and Political Sciences, \\ UniversitasMalikussaleh, Lhokseumawe, Indonesia \\ Email : ferizaldi@unimal.ac.id
}

\begin{abstract}
Through Law no. 11 of 2006 concerning the Government of Aceh. Aceh has very broad powers, especially in the area of fiscal decentralization, which allows the Aceh government to have greater discretion in maximizing its fiscal needs. The phenomenon that occurred in North Aceh is very paradoxical with the fact that the North Aceh Government experienced a very large budget deficit after the end of PT. Arun. LNG as a contributor to oil and gas revenue sharing. This study aims to find out what innovation policies are carried out by the North Aceh Regency Government to overcome the budget deficit after the end of PT. Arun LNG. The results of the study show that various policies have been carried out by the North Aceh government but are still short-term in nature. So it can be concluded that the North Aceh Government does not have Social Accountability in implementing Aceh's Special Autonomy. In the Medium-Term Development Plan, a major policy that is substituted for income that will be lost after the end of the operations of PT. Arun.LNG so that the budget deficit can be overcome and the regional fiscal gap does not become negative.
\end{abstract}

Keyword :Inovation, Regional Fiskal, Government 


\section{Introduction}

RyassRasyid said the regional autonomy policy which was launched in 1999 was intended to strengthen the authority of local governments and encourage community independence in the regions. The powerlessness of the regions in developing policy initiatives has long been maintained through a system designed in a centralized manner, with dependence on development projects designed through the legality of Presidential Instructions and other forms. ( Jazuli, 2007: xviii )

So that with the regional autonomy policy, the region will grow and develop according to the characteristics and potential of each. The pattern of dependence with the central government will decrease along with the birth of regional innovation and creativity, which is driven by regionalleaders. This is in line with the statement of Widjaya (2002:7) who also said that through regional autonomy it is hoped that the regions will be more independent in determining all theiractivities and the central government is expected not to be too active in regulating regions with a centralized pattern.

Aceh Province in implementing decentralization or regional autonomy policies is different from other provinces in Indonesia. With Law no. 18 of 2001 concerning Special Autonomy for Nanggroe Aceh Darussalam as well as being a dignified effort for early conflict resolution in Aceh as well as a new paradigm in reducing the centralization of power. This was followed by the enactment of Law no. 11 of 2006 concerning the Government of Aceh. In Law No. 11 of 2006 the authority of the Acehnese government is greater in various matters including fiscal decentralization, political decentralization, cultural and religious decentralization.

Specifically in the field of fiscal decentralization, the province of Aceh is entitled to receive larger funds from the oil and gas revenue-sharing sector, and to receive additional transfers other than general allocation funds and special allocation funds, namely special autonomy funds. Oil and gas revenue sharing fund according to UUPA No.11 of 2006 concerning the Government of Aceh is 70: 30, 70 percent for the Province of Aceh and 30 percent for the Government of Indonesia.

Prof. Dr. ApridarMSi, said that Aceh, in particular the government and people of North Aceh Regency, may now or in the future enter a period of "distress", following the end of PT Arun's operations in mid-October 2015. Sadly, the Aceh Government and the North Aceh Regency Government are considered to have no preparations. -what "welcome" the cessation of natural gas exploitation in the Arun field.

The blueprint should have been prepared since the 1980s. However, the North Aceh Regency Government is just sitting around waiting for the results every year, ", responding to PT Arun's "roll 
lapak". The wealth and glory of the Government and the people of Aceh, especially North Aceh, is highly dependent on the results of natural gas exploitation by PT Arun since 1977. So, now the big question that arises is "what do you want after Arun goes out of business? " In the future, the North Aceh Regency Government should focus on the agriculturalsector to reduce poverty. Development priorities to reduce poverty must also be directed at sustainable economic development in rural areas," ( Serambi Indonesia, 17 January 2017 )

The impact of the end of the operation of PT. Arun LNG as a contributor to oil and gas revenue-sharing for North Aceh, the North Aceh District Budget (APBK AUT) has a deficit. As for the things that the North Aceh Government has done to overcome this is to apply for a budget loanto the Ministry of Finance, the article is that after the approval of the 2016 APBK, North Aceh did not meet the budget of Rp110 billion.

Quoting the opinion of Cohen and Peterson and the OECD (Mas'ud Said, 2005:25) they explain that regional autonomy can promote an efficient and creative government administration system, and the OECD argues that regional autonomy can increase the effectiveness of the public sector. So the North Aceh Government should be innovative in producing policies that can maximize regional income as a source of development and public services in the region. Based on this phenomenon, in the task of this article, the author tries to discuss the innovative policies carried out by the North Aceh government to replace lost sources of revenue from the oil and gas revenue sharing sector.

\section{Literature review}

\section{Public policy}

Policies are often misinterpreted by some people, policies are often interpreted as something that violates procedures or is considered as an exception and so on which has a negative meaning. This negative interpretation is closely related to policies that are interpreted by the public as partial, or only interpreted according to stereotypes. Public policy consists of two words, namely "policy" and "public", policies issued by the government with the authority it has, while public means the wider community or people who give authority to the government. So the policy should be directed to carry out the authority possessed in accordance with the will of the community for the common good.

The definition of public policy as mentioned by Thomas R. Dye (1995:2) " what government does, why they do it, and what difference it makes". Furthermore, Peterson (2003:1030) states public policy as government action to address some problems. The definition of public policy as expressed by Dye is still too vague, whatever the government does or does not do, this 
means that the silence of the government means a policy that is carried out, it could be that the government's silence may be because it does not understand the problems and problems of its people, but this understanding is generally accepted as a simple concept of public policy.

While Peterson describes it as a government action to solve some problems. I hope the definition is broader than Dye. While the key concepts of public policy as described by Young and Quinn (in Suharto, 2005:44) are as follows:

1. Authorized Government action;

2. A Reaction to real world needs and problems;

3. A goal-oriented set of actions;

4. A decision to do or not to do something;

5. A Justification made by one or more actors.

Based on these key concepts, it can be concluded that public policy is only carried out by the government with the power it has in resolving community problems to reach a final settlement,the policy itself is usually comprehensive, meaning that it consists of various actions that are structured as a formal legality that is binding and can be measured. its success.

If translated in the context of the Unitary State of the Republic of Indonesia, public policies can be classified as:

1. Public Policy as a Reference, namely the highest legal aspect that regulates problems in general, for example the MPR - RI Decree during the New Order.

2. Main Public Policy, namely the legal aspect that translates the Reference policy to be implemented. For example, Laws or Presidential Decrees.

3. Implementing Public Policy, namely the legal aspect that transforms the main policies into principal and technical rules, for example the Decree of the Minister, Governor or Regent/Mayor.

According to Winarno (2007:32-34), the process of making public policy is a complex process because it involves many processes and variables that must be studied. Therefore, some political experts who are interested in studying public policy divide the processes of public policy making into several stages. The stages of public policy are as follows:

\section{Agenda Preparation Stage}

Elected and appointed officials put matters on the public agenda. Previously, these problems had the competence to be included in the policy agenda. In the end, several issues entered the policy agenda of the policy makers. At this stage a problem may not be touched at all, while other problems are set to be the focus of discussion, or there are also problems for certain reasons that are postponed for a long time. 


\section{Policy Formulation Stage}

Issues that have entered the policy agenda are then discussed by policy makers. These problems are defined and then the best solution is sought. The solution to this problem comes from various alternatives or policy options (policy alternatives / policy options). Similar to the struggle for a problem to enter the policy agenda, in the policy formulation stage each alternative competes to be selected as a policy taken to solve the problem. At this stage, each actor will "play" to propose the best solution to the problem.

\section{Policy Adoption Stage}

Of the many policy alternatives offered by policy makers, in the end one of the policy alternatives was adopted with the support of the legislative majority, consensus between the directors of the institution or judicial decisions.

\section{Policy Implementation Phase}

A policy program will only become elite records, if the program is not implemented. Therefore, the policy program decisions that have been taken as alternative solutions to the problem must be implemented, that is, carried out by administrative bodies and government agencies at lower levels. The policies that have been taken are implemented by administrative units that mobilize financial and human resources. At this stage of implementation, various interests will compete with each other. Some of the implementation of the policy has the support of the implementers (implementors), but others may be opposed by the executor.

\section{Policy Evaluation Stage}

At this stage the policies that have been implemented will be assessed or evaluated, to see how far the policies made have been able to solve the problem. Public policy is basically made to achieve the desired impact. In this case, solving the problems facing society. Therefore, the measures or criteria that become the basis for assessing whether public policies have achieved the desired impact are determined.

\section{Government Innovation}

Rogers (2003) as quoted by Budi Prayitno (2016) describes that innovation is an idea, idea, action/practice or object that is realized and as something new by individuals and groups that are adopted in their environment. Based on these two ideas, the meaning of innovation is defined as system renewal that can be adopted into the environment. In this case, the reform in question is a housing policy that focuses on reforming policies that are considered failed. Even the meaning of innovation is also considered as the basis for economic development and the like in developing countries.

Furthermore, Peter Drucker (1986), argues that every organization needs a core competence (core competence). With innovation will encourage organizational 
growth, increase future success, and is the driver that allows organizations to survive vulnerabilities (viability).

Drucker (1986) also stated that specifically, systematic innovation means controlling the seven sources of innovation opportunities. The first four sources are within the organization, both business and community service institutions, or within the organization. Furthermore, the second three sources are changes that occur outside the organization, or external aspects.

Furthermore, there are five principles that can foster innovation from within the individual or personal or organization. The five principles in question include:

1. Purposeful and systematic innovation, starting with analyzing the sources of innovative opportunities.

2. Conceptual and perceptual innovation. The must for innovation is to go out to see, ask and listen, pay attention to customers, users, learn their expectations, assess their needs.

3. To be effective an innovation must be simple and must be focused.

4. Effective innovation starts small, at first it requires minimal funds, limited people, and only a small and limited market.

5. A successful innovation must lead to leadership in a given environment.

\section{Research methods}

The selection of the research method was carried out by looking at the characteristics of the research, to conduct research on poverty alleviation in the district of North Aceh, it was deemed appropriate to use an exploratory descriptive qualitative approach. Explorative descriptive research method aims to describe the state of a particular phenomenon. In this study was not intended to test specific hypotheses not only describe what the presence of a variable symptoms or specific circumstances. (Arikunto, 2002:243). So that the researcher does not establish a hypothesis, but only establishes a symptom or phenomenon. The symptom or phenomenon in question is the phenomenon of poverty in North Aceh district which is detailed in the focus of the research.

\section{Research sites}

This research was conducted in North Aceh District, the locus of which was at the North Aceh District Secretariat and the North Aceh Bapedda Office. The informants are the Deputy Regent of North Aceh, the Regional Secretary and the Secretary of the Bapedda of North Aceh Regency.

\section{Data collection technique}

According to Burhan (2008: 107) the most independent data collection methods in qualitative research on all data collection 
methods and data analysis techniques are indepth interviews, participatory observation, and documentary materials.

\section{Data Analysis Techniques}

Planned in this study $\mathrm{d}$ ata were analyzed qualitatively by using a model of descriptive analys . Glaser and Straus (Faisal, 1999: 198) suggested that descriptive analysis through the following procedures:

1. Descriptive analysis by developing categories consisting of the results of indepth interviews and the sources according to the indicators that exist in each variable and these categories are obtained in accordance with the interview guidelines that have been prepared.

2. The interpretation of the results of the descriptive analysis based on the theory - the theory of the corresponding de ngan research

\section{Results and Discussion}

Local government innovation in the era of regional autonomy, is something that must always be considered by local governments to increase the capacity of local governments in realizing political and social accountability to advance their regions in the context of strengthening local government. With regard to regional financial policies, it is very important to create a positive fiscal gap.

The problem of the budget deficit in the North Aceh Regency Government should have been anticipated well in advance, this indicates that the capacity of the Regional Government in carrying out its functions is very poor. This is in line with the view of Peter Drucker (1986) who argues that every organization needs a core competence, namely an innovation that is planned to solve various regional problems. Innovation will drive organizational growth, increase future success, and is the engine that allows organizations to survive vulnerabilities (viability).

So in the preparation of the RPJMD ( Regional Medium-Term Development Plan) must go through a careful assessment through the preparation of comprehensive policies through regional development planning. In line with the opinion of Winarno (2007:32-34) which mentions the stages of complex policymaking that involve many processes and variables that must be studied.

The above must start from the stage of preparing the regional government's financial policy agenda in the RKPD or Strategic Plan SKPD must schedule several alternative policies to replace lost income in the 2016 and 2017 APBK and so on. Which will be adopted in the APBK to be implemented in DPA-SKPD as a strategic policy, considering the amount of lost income is very large, reaching more than 75 billion, this will have an impact on regional financial performance.

Regional financial performance seen from the revenue side (fiscal availability) is 
the ability of the region that is available purely from PAD. The ratio of PAD to Total Regional Revenue shows the fiscal independence of a region. The higher the contribution of PAD, the higher the ability of local governments to implement decentralization. The formulation of the degree of Fiscal Decentralization proposed by Halim (2008:262), is to compare the percentage of PAD and total regional revenues, so that to maximize regional financial performance, innovative and actual policies are needed.

The actual policies carried out by the North Aceh government at this time are through the submission of regional debt and streamlining the organizational structure for budget efficiency. After an evaluation of the 2016 North Aceh APBK, a number of programs that have been proposed by the executive and legislature, it turns out that there is an insufficient budget of Rp. 110 billion from the approved budget of more than Rp. 2.2 trillion. "To meet the program budget that has been proposed by the executive and legislature, the solution is to apply for a loan. This step taken by the North Aceh Government is for the benefit of the Acehnese people, so that the program that has been proposed in the Development Planning Deliberation (Musrenbang) can be implemented as expected. Public. The Director General of Finance has agreed, but there are a number of documents that must be corrected. Under the regulations, if the province or district/city does not have sufficient budget, it is justified to apply for a loan to the Ministry of Finance.

To overcome the problems surrounding the reduction of oil and gas revenue-sharing funds after the end of the existence of PT. Arun. LNG. The North Aceh government has implemented various innovative policies, including applying for loans and efforts to restructure the government bureaucracy for budget efficiency. The District Government (Pemkab) of North Aceh removed 38 echelon IV positions in the new work system organization structure (SOTK), which had been proposed to the Ministry of Home Affairs (Kemendagri). The echelon IV positions are at the level of subsection head (kasubbag) and section head (kasi).

The results of the SOTK downsizing were conveyed by the Acting Secretary (Plt) of the North Aceh Regional Secretariat, Abdul Aziz MH, who stated that currently there are 900 positions in 30 offices/agencies/offices within the North Aceh Regency Government starting from Echelon II, III, and IV. Inthe new SOTK, 862 positions are proposed. This means that there is a reduction of 38 positions. The establishment of the new SOTK was carried out based on Government Regulation No. $18 / 2016$. The goal is to improve budget efficiency. With the reduction of the organizational structure automatically will save the budget. Because 
there are 38 people who no longer need to be paid allowances.

The policy is not yet complete in solving problems and is less innovative, the North Aceh district government should think about analyzing its financial ratios to ensure sufficient fiscal gaps in carrying out development and public services. In this regard, Badrudin in Aris (2017) states that the results of the analysis of the financial ratios of a regional budget can be used as a benchmark in order to: a) Assess regional financial independence in financing the implementation of regional autonomy; $b$ ) Measuring effectiveness and efficiency in realizing regional income; c) Measuring the extent to which local government activities spend local revenues; d) Measuring the contribution of each source of income in the formation of regional income; and e) Observing the growth/development of income and expenditure acquisition during a certain period of time. Thus, social accountability is needed as a form of longterm innovation in regional financial management.

\section{Recommendation}

The regional debt policy and streamlining of the organizational structure as implemented by the North Aceh government are insignificant short-term innovations, meaning that the budget deficit will always cover the North Aceh APBK, and this is evident from the North Aceh Perbub No. 37 of 2017 dated 23 February 2017 in the
Oil and Gas Revenue Sharing component to "Nil". This fact proves that the North Aceh Government does not have Social Accountability in implementing Aceh's Special Autonomy. The RPJM should have planned a major policy that is a substitution of income that will be lost after the end of PT. Arun. LNG so that the budget deficit can be overcome.

\section{References}

Halim, Abdul, 2008, AkuntansiKeuangan Daerah, Edisi 3, PenerbitSalembaEmpat, Jakarta

Thomas R. Dye, 1995, Understanding Public Policy, Prentise Hall, USA

KebijakanPublik; 2002, Teoridan Proses (Edisirevisi) Penulis : Budi Winarno. Media Presindo Yogyakarta

Budi Prayitno, dkk , 2016. SkemaInovatifPemenuhanKesejaht eraanAtasPapan.JurnalKawistara No. 1 Vol 6.UGM. Yogyakarta

Drucker, Peter., $1986 . \quad$ Innovation andEntrepreneurship. GramediaPustakaUtama, Jakarta

Juwaini Jazuli, 2007, Otonomi Sepenuh Hati, Pokok-pokok pikiran untuk perbaikan implementasi otonomi daerah, AL-I'Tishom, Jakarta

RanteAris, et al, 2017. AnalisisKemandirianKeuangan Daerah, Jurnallnovasi Vol.13 No.2 Tahun 2017.UniversitasMulawarman.

Diaksesdari http://journal.feb.unmul.ac.id/in dex.php/INOVASI

Said Mas'ud, 2005,Arah Baru Otonomi Daerah di Indonesia, UMM Pres, Malang. 
Widjaja, 2002, Otonomi Daerah dan Daerah Otonom, PT. RajaGrafindo PersadaJakarta http://www.acehtrend.co/defisit-anggaranaceh-utara-ajukan-pinjaman-kedepartemen-keuangan/3 Maret 2016. 